\title{
Geoelectric Sounding for Evaluating Soil Corrosivity and the Vulnerability of Porous Media Aquifers in Parts of the Chad Basin Fadama Floodplain, Northeastern Nigeria
}

\author{
Muraina Z. Mohammed ${ }^{1}$, Martins O. Olorunfemi ${ }^{2} \&$ Alex I. Idonigie ${ }^{3}$ \\ ${ }^{1}$ Department of Geology, Adekunle Ajasin University, Akungba-Akoko, Nigeria \\ ${ }^{2}$ Department of Geology, Obafemi Awolowo University, Ile-Ife, Nigeria \\ ${ }^{3}$ Formerly of Department of Geology \& Mining, University of Jos, Jos, Nigeria \\ Correspondence: Muraina Z. Mohammed, Department of Geology, Adekunle Ajasin University, PMB 001, \\ Akungba-Akoko, Nigeria. Tel: 234-816-4212-112. E-mail: drmmohammed@yahoo.com
}

Received: April 5, 2012 Accepted: June 15, 2012 Online Published: June 26, 2012

doi:10.5539/jsd.v5n7p111 URL: http://dx.doi.org/10.5539/jsd.v5n7p111

\begin{abstract}
A geoelectrical survey was carried out in parts of the Chad Basin Fadama Floodplain as a means of evaluating both the soil corrosivity and protective capacity. One hundred and six Schlumberger Vertical Electrical Sounding data were collected at the corners of a $225 \times 225 \mathrm{~m}$ square grid network. Topsoil resistivity and topsoil longitudinal unit conductance maps were generated from the first and second order geoelectric parameters respectively. Areas considered as high corrosivity are the north central, southwestern, southern and northern parts with $(\rho<180 \Omega-m)$. Part of the study area characterized by materials of poor to weak protective capacity has longitudinal conductance values of less than 0.1 and $(0.1-0.19)$ mhos respectively. Values between $(0.2-0.79$ mhos - sandy clay cover) and (0.8 - 4.9 mhos - clay cover) correspond to moderate and good protective capacity respectively. It can thus be concluded that the flanks of the floodplain underlain by appreciable clayey topsoil thickness columns are susceptible to corrosion tendency. These same flanks are characterized by materials of moderate to good protective capacity and serve as sealing potential for the underlying hydrogeological system in the area.
\end{abstract}

Keywords: geoelectrical, survey, floodplain, corrosivity, protective, capacity, vulnerability, sealing

\section{Introduction}

Underground storage tanks for petroleum products, septic tanks, agricultural activities, municipal landfills, military installations, nuclear sites, waste infiltration systems and abandoned hazardous waste sites are generally considered major threats to groundwater/hydrogeologic system or porous media aquifers (Mohammed, 2007).

Fadamas floodplain is part of the wetland regions of the West Chad Basin located between Azare and Jama'are towns, northeastern Nigeria. In recent times, efforts by the Federal government and other governmental agencies in areas of water supply and crop production have led to improvement of the lives of the people around the area through farming and animal husbandry. Agricultural activities in many parts of the area may portend serious environmental/hydrogeological threats, particularly in respect of the accessibility of porous/alluvial sand water table aquifers to pollution. The vulnerability of these aquifers to pollution may be considerably high as the continuous and extensive use of chemical fertilizers/pesticides, the drainage or wash off of animal solid wastes disposal from nomadic grazing activities, and flood activities remained. Man's activities ranging from land fill solid wastes disposal to liquid wastes disposal etc. may also remain a contributory factor.

However, contamination of the hydrogeologic system in most porous media areas is a common global feature (Oladapo et al., 2004; Mohammed, 2007). The World Health Organization estimated that more than $20 \%$ of the world population (around 1.3 billion people) has no safe drinking water and that more than $40 \%$ of all population lack adequate sanitation (Oastridge \& Trent, 1999). Many developing countries are still faced with difficult choices as they find themselves caught between finite and increasing polluted water supplies on one hand and rapidly rising demand from urbanization on the other hand (Forum Umwelt \& Entwickling, 2001). The need then arises to assess the protective capacity of the superficial materials (topsoil overlying the alluvium aquifer) of aquifer to enable the evaluation of the level of protection of the hydrogeological systems against surface sourced 
pollution. Also, the degree of soil corrosivity may be evaluated should metal pipes be required for reticulation works in the groundwater development within the area.

Geoelectrical resistivity method has been adopted for this study since it is one of the most effective geophysical tools for groundwater and environmental investigations. The superiority of the method over other methods is confirmed in the work of Zohdy (1973); Zohdy, Eaton and Mabey (1974); Ako and Olorunfemi (1989); Mbonu, Ebeniro, Ofoegbu and Ekine (1991); Olayinka and Olorunfemi (1992); Olorunfemi and Fasuyi (1993); Mohammed (2007).

\section{Description of the Study Environment}

\subsection{Location and Areal Extent}

The study area is the River Jama'are floodplain in the West Chad Basin. It is situated on the northern side of the Azare - Jama' are highway, about $30 \mathrm{~km}$ West of Azare town in Katagum Local Government Area of Bauchi-State (Figure1). It is confined within longitudes 9 $9^{\circ} 56^{\prime} 30^{\prime \prime} \mathrm{E}$ and $9^{\circ} 58^{\prime} 00^{\prime \prime} \mathrm{E}$ and latitudes $11^{\circ} 39^{\prime} 15^{\prime \prime} \mathrm{N}$ and $11^{\circ} 41^{\prime} 15^{\prime \prime} \mathrm{N}$ (FSN, 1978) which approximate eastings and northings of $602631.843 \mathrm{mE}$ and $605356.818 \mathrm{mE}$ and 1288367.009 $\mathrm{mN}$ and $1292062.197 \mathrm{mN}$ of the Universal Traverse Mercator (UTM) Mina Zone 31 coordinates respectively.

The study area covers an areal extent of about 4.53 Kilometers square and situated on approximately flat terrain with average surface elevation of about $370 \mathrm{~m}$ above sea level. A local topographic high exist as the northern edge of the area at Yola settlement. This makes the entire area vulnerable to periodic flooding at the peak of rainy season.

\subsection{Geology and Hydrogeology}

The study area is underlain by Cretaceous-Tertiary Chad Formation and Recent alluvial Formation of Pleistocene age. The two formations directly rest on the basement bedrock rock (Figure 2). However, rocky hills and inselbergs of the basement rock occur around Geidam, Gumel and Shira, about $30 \mathrm{~km}$ southwest of the study area. This suggests that the study area is located within a transitional sedimentary/basement terrain. The major geological features in the area include approximately NW-SE trending geophysically identified suspected deeply buried regional parallel faults/fractured zones in the basement bedrock.

The alluvium deposits with the flood plain consist of silts, clays, and sands, while the Chad Formation is composed of Quaternary sediments of lacustrine origin (Carter et al., 1963). The basis of gravels constitute the main aquifer with which the silts clays the aquitard (GSN, 1978; BSADP, 1988; Matheis, 1989; Offodile, 1992, 2002).

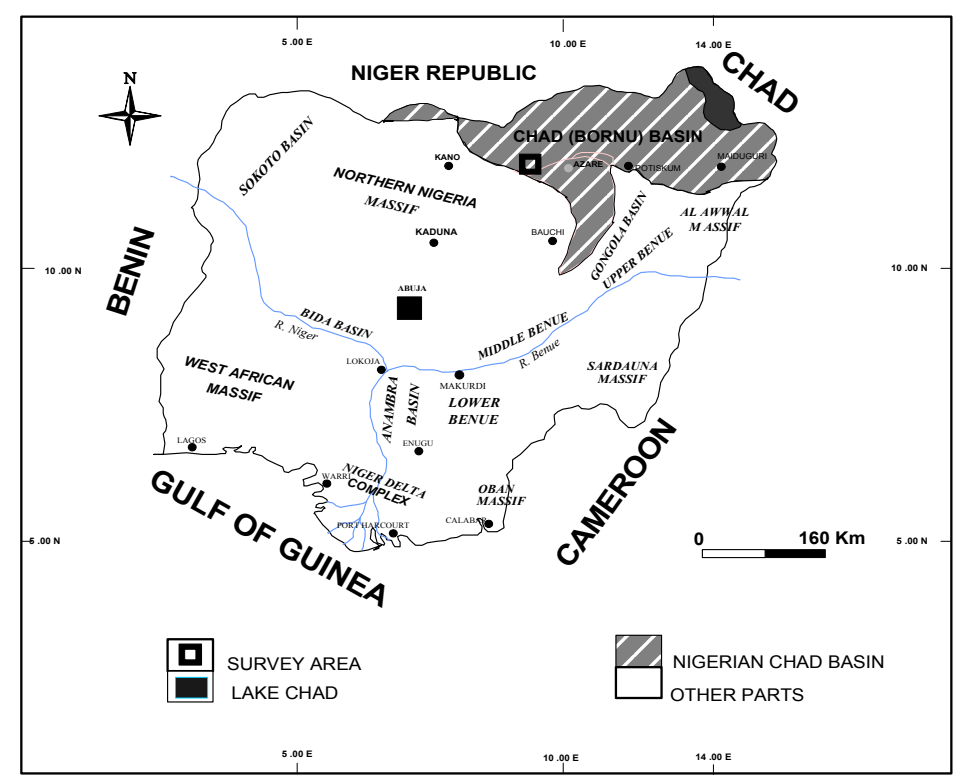




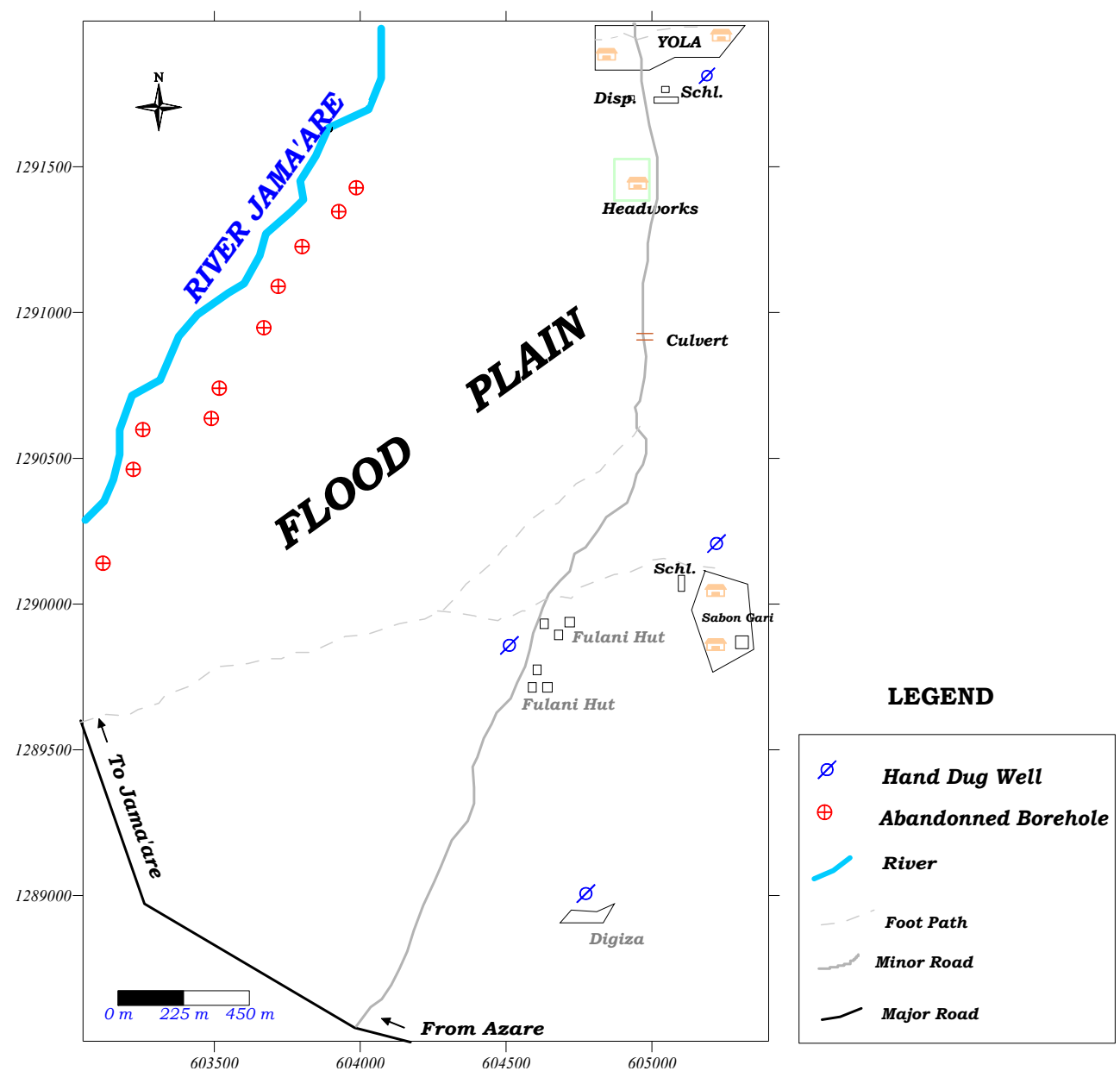

Figure 1. Map of the study area showing the floodplain of River Jama'are 


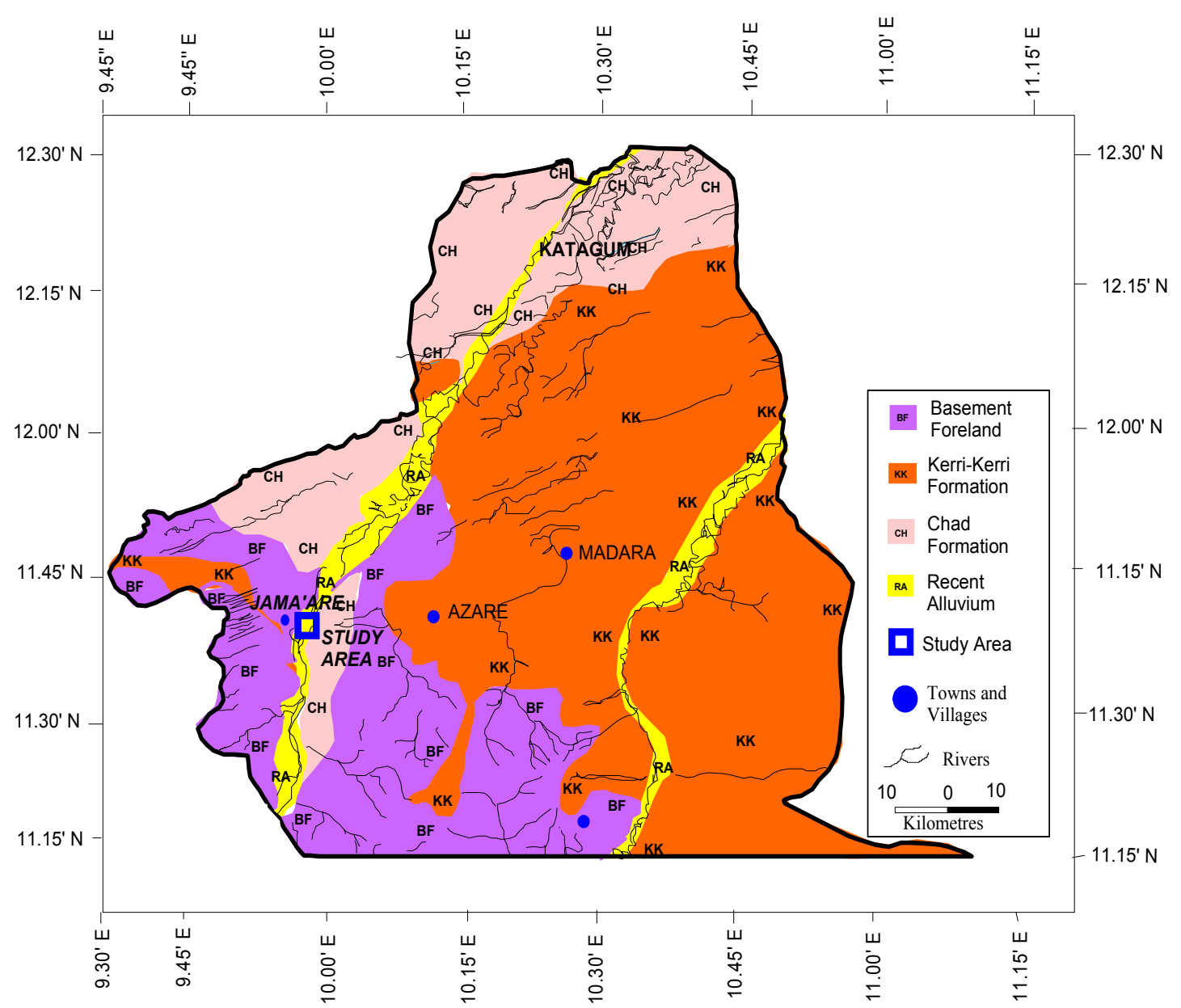

Figure 2. Geological/Hydrogeological map of the Northern Bauchi State showing the study area

\section{Materials and Method of Study}

\subsection{Data Collection Techniques}

Apparent resistivity data were collected at One hundred and six stations (Figure 3) by the use of the Schlumberger Vertical Electrical Sounding (VES) technique. The inter-electrode spacing $(\mathrm{AB} / 2)$ of the array used was varied from 1-225 m with a maximum spread length of $450 \mathrm{~m}$. The PASI 16 Digital Resistivity Meter was used for the data collection.

\subsection{Data Processing/Interpretation Techniques}

The quantitative interpretation of the sounding data involved partial curve matching and computer aided interpretation techniques. The VES interpretation results (layer resistivities and thicknesses) were later used to derive the second order geoelectric - the so-called Dar Zarrouk parameters (Maillet, 1947; Henriet, 1976, Niwas \& Singhai, 1981; Oladapo et al., 2004). These parameters include the Longitudinal Unit Conductance $\left(\mathrm{S}_{\lambda}\right)$, Transverse Unit Resistance $\left(T_{\lambda}\right)$, Longitudinal Resistivity $\left(\rho_{\mathrm{L}}\right)$, Transverse Resistivity $\left(\rho_{\mathrm{t}}\right)$ and Coefficient of Anisotropy ( $\lambda$ ) (Zohdy et al., 1974).

For $\mathrm{n}$ parallel layers of resistivities $\rho_{\mathrm{i}}, \ldots \ldots \ldots \rho_{\mathrm{n}}$, and thicknesses $\mathrm{h}_{\mathrm{i}}, \ldots$ section (Figure 4). $\mathrm{h}_{\mathrm{n}}$ as shown in a typical geoelectrical

The total longitudinal unit conductance (S) is defined as:

$$
S=\sum_{i=1}^{n} \frac{h_{i}}{\rho_{i}}
$$


The total transverse unit resistance $(\mathrm{T})$ is defined as:

$$
T=\sum_{i=1}^{n} h_{i} \rho_{i}
$$

The average longitudinal resistivity $\left(\rho_{\mathrm{L}}\right)$ is defined as:

$$
\rho_{L}=\frac{H}{S}=\frac{\sum_{i=1}^{n} h_{i}}{\sum_{i=1}^{n} \frac{h_{i}}{\rho_{i}}}
$$

The average transverse resistivity $\left(\rho_{\mathrm{t}}\right)$ is defined as:

$$
\rho_{t}=\frac{T}{H}=\frac{\sum_{i=1}^{n} h_{i} \rho_{i}}{\sum_{i=1}^{n} h_{i}}
$$

The coefficient of anisotropy $(\lambda)$ is defined as:

$$
\lambda=\sqrt{\frac{\rho_{t}}{\rho_{L}}}=\frac{\sqrt{T S}}{H}
$$

The subscript $\mathrm{i}$ indicates the position of the layer in section.

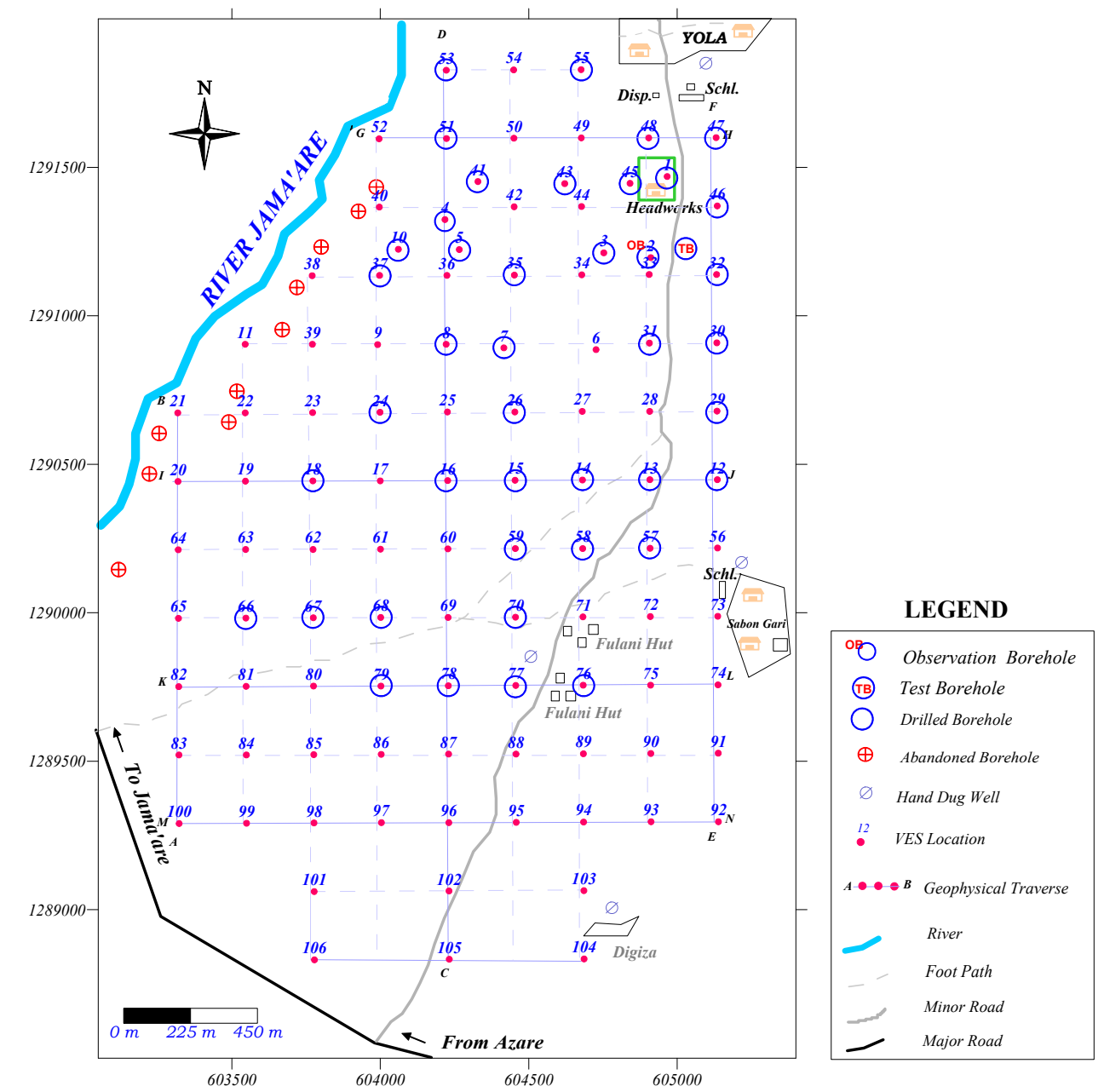

Figure 3. Data acquisition map showing VES stations, traverses and location of boreholes drilled and completed 


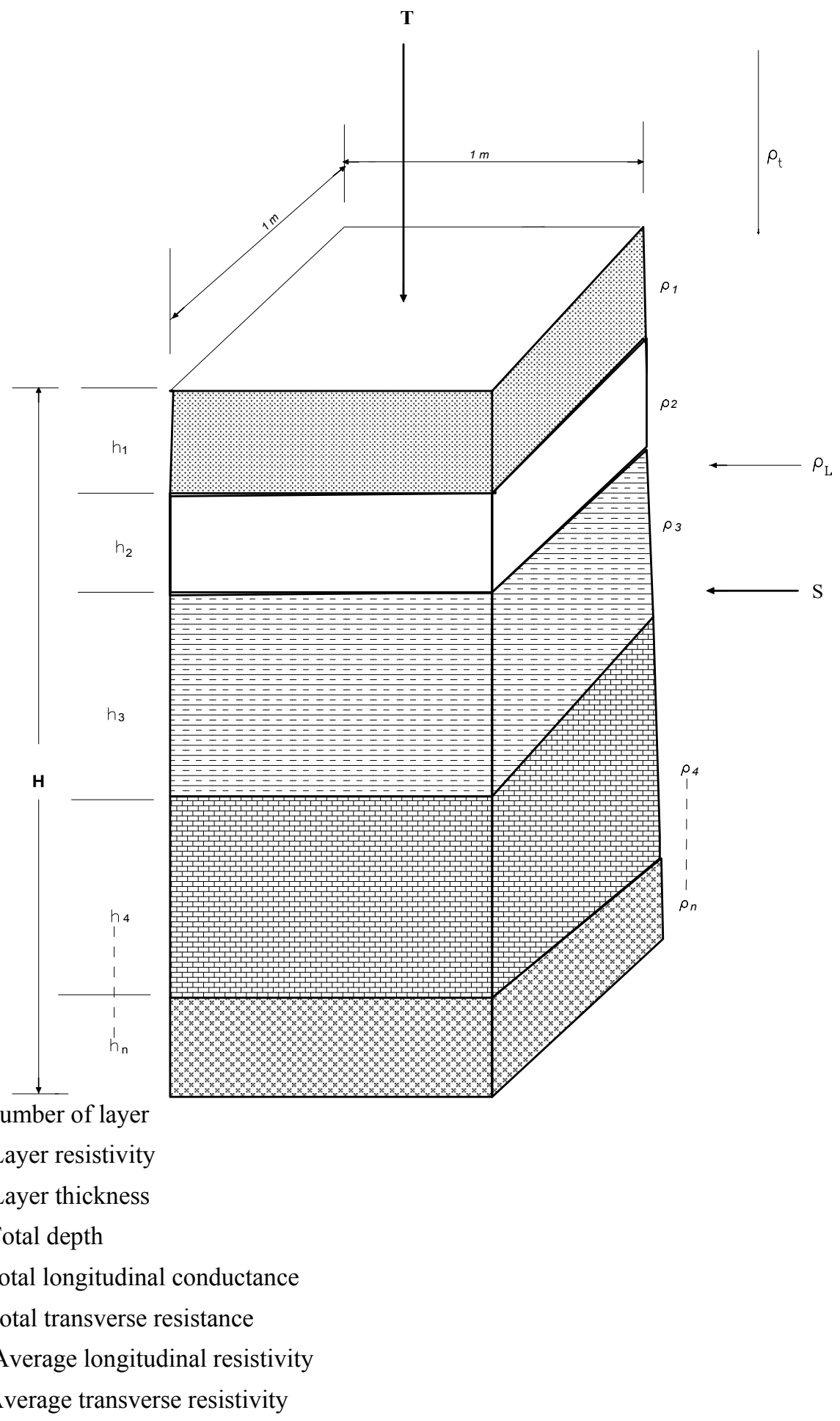

Figure 4. A typical geoelectrical section

\section{Results and Discussion}

\subsection{Geoelectric Results}

The results are presented as vertical electrical sounding curves displaying the geoelectric parameters (layer resistivities and thicknesses), corrosivity and longitudinal conductance maps.

The VES curves show a range of 4-geoelectric layers $(\mathrm{KH}, \mathrm{QH})$ to complex 5-geoelectric layers $(\mathrm{HKH}, \mathrm{KQH}$, $\mathrm{QQH}$ ) and 6-geoelectric layers (QHKH and KHKH) (Figures 5a \& b). 
The topsoil resistivity shows values that range from $0-250 \mathrm{ohm}-\mathrm{m}$ with the higher frequency in the $0-250 \mathrm{ohm}-\mathrm{m}$ range. The mean is $325 \mathrm{ohm}-\mathrm{m}$ while the standard deviation is $892 \mathrm{ohm}-\mathrm{m}$. This indicates a very high degree of dispersion with a coefficient of variation of $274.5 \%$. This variation may be explained by the wide textural/compositional variation in the topsoil. Seasonal variations in the amount of available recharge and topographic elevation/depth of water table may have also affected the soil resistivity.

The topsoil resistivity values that are less than $100 \mathrm{ohm}-\mathrm{m}$ typify clay while high resistivity ( $\rho>100 \mathrm{ohm}-\mathrm{m}$ ) may suggest sandy clay, clayey sand, sand, compact sand or lateritic column (Ako \& Olorunfemi, 1989; Olayinka \& Olorunfemi, 1992; Olorunfemi \& Okhue, 1992; Omosuyi et al., 2003; Oladapo et al., 2004). Resistivity values in the range of $(\rho>1000 \mathrm{ohm}-\mathrm{m})$ white lateritic sand (hard pan) and sand observed at few places, particularly in the topographical high areas in the northern and western edges of the site. The thickness of the topsoil ranges from 0.4 to $6.7 \mathrm{~m}$, but is generally less than $3 \mathrm{~m}$ with the most frequently occurring values in the $1.0-2.0 \mathrm{~m}$ range.

\subsection{Soil Corrosivity Evaluation}

Soil resistivity values can be classified in term of soil corrosions as shown in Table 1.

The first layer resistivity values obtained from the interpretation results were utilized in generating corrosivity map (Figure 6). The map is used in the evaluation of the degree of soil corrosivity, at shallow depth, in the area, should metal pipes/buried utilities be required for reticulation works in the groundwater development and other engineering utilities.

The areas considered to be of high corrosivity are the north central, southwestern southern and northern parts of the area. These areas are characterized by relatively low resistivity values $(\rho<180 \Omega-m)$. Areas with high resistivity values $(>180 \mathrm{ohm}-\mathrm{m})$ are precisely non corrosive. These areas include the eastern, part of the southern and western parts of the area. The eastern flank is particularly overlain by lateritic hardpan with relatively high resistivity values.

More than $60 \%$ of the study area displays a relatively low topsoil resistivity values with high tendency for corrosivity. Hence, metallic utilities/pipes etc buried within the areas with high degree of corrosivness are susceptible to corrosion.

\subsection{Overburden Protective Capacity Evaluation}

The ability of an earth medium to retard and filter percolating fluid is a measure of its protective capacity (Olorunfemi et al., 1999). Henriet (1976) described the protective capacity of an overburden exerted by retardation and filtration of percolating pollutants as being proportional to its thickness and inversely proportional to its hydraulic conductivity. Clayey material content is generally characterized by low permeability, low resistivity, low hydraulic conductivity and longitudinal unit conductance values. Hence the protective capacity can be considered as being proportional to the longitudinal conductance (S). That is, the higher the overburden longitudinal conductance of an area, the higher its protective capacity.

The modification of Henriet (1976) and Oladapo et al. (2004) classifications shown in Table 2 is adopted to suite the evaluation of the protective capacity of this basement/sedimentary transition environment. Figure 7 is the map of the longitudinal unit conductance (S) of the superficial materials (topsoil) constructed from the topsoil longitudinal unit conductance (s) values. The values vary between 0.00044 and 0.61 mhos. Values between 0.2 and 0.79 mhos typically correspond to moderate protective zones (sandy clay cover), such zones are distinguished as small pockets or closures found scattered within the map region, while pockets of blank found at the southeastern and northern ends typify good protective capacity $(0.8$ and 2.2 mhos $)$ on the map. The remaining segments of the map constitute about $95 \%$ of the total areal extent of the study area are characterized by materials of poor to weak protective capacity $(<0.1$ and $0.1-0.19)$ mhos respectively. This area may be highly proned to pollution. 
(KH)

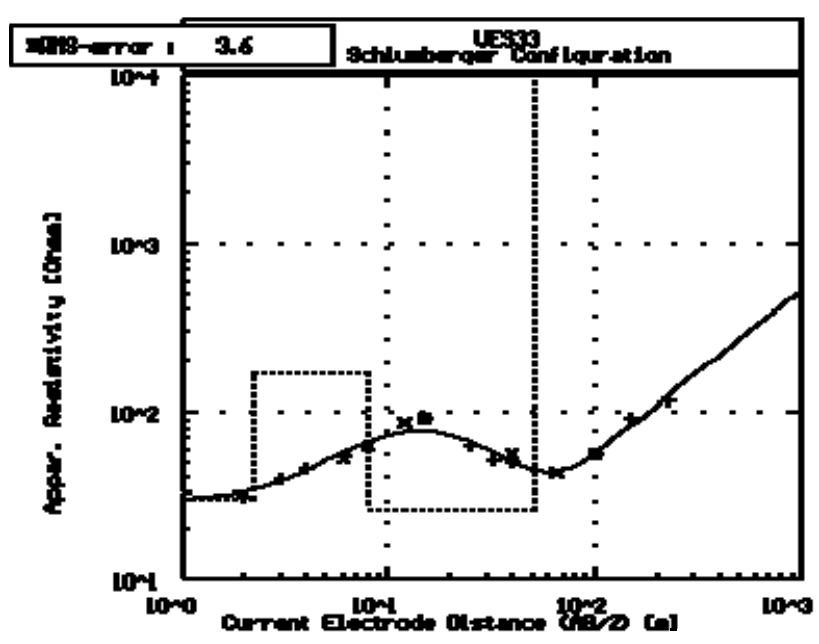

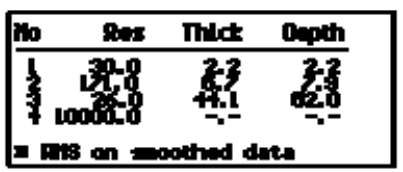

(QH)

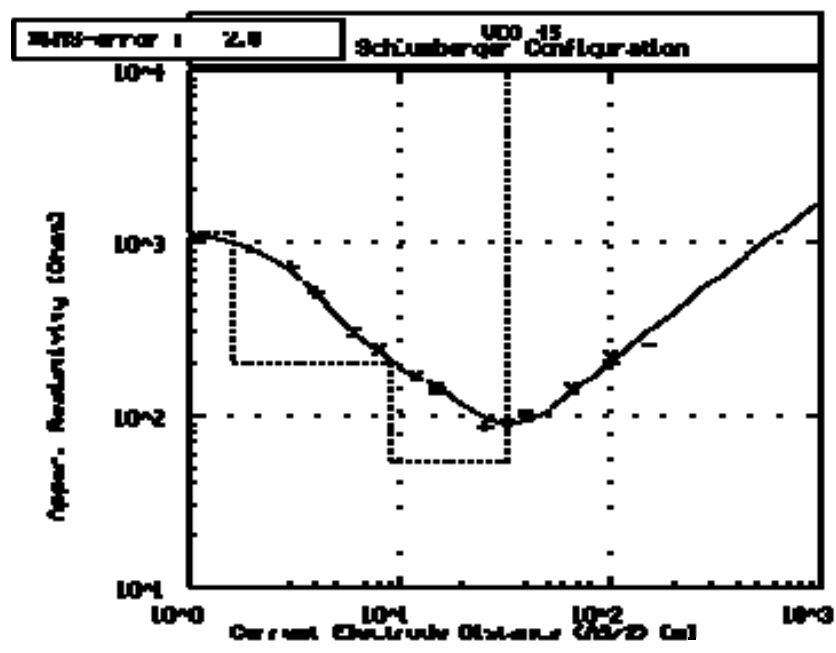

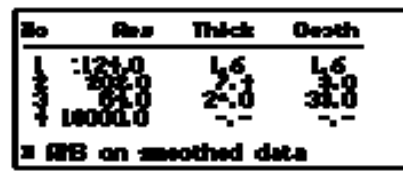

(QQH)
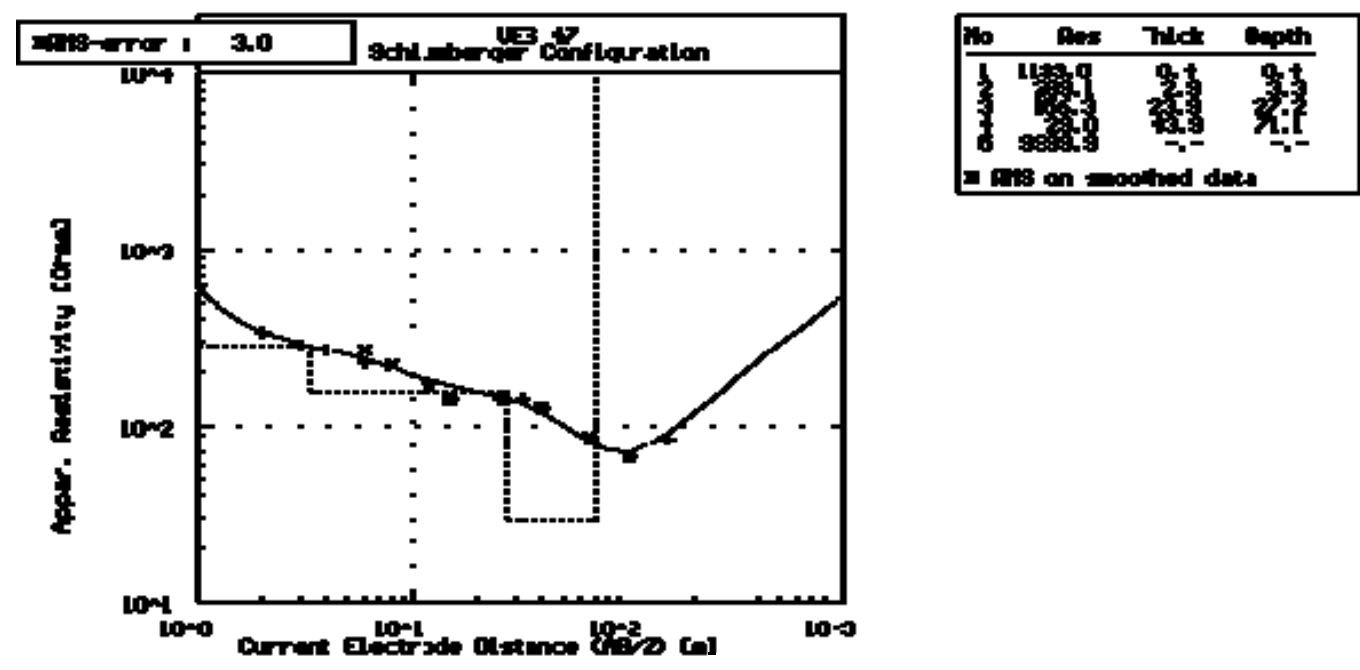

Figure 5 (a). Computer interpretation results and curve types 
(KQH)
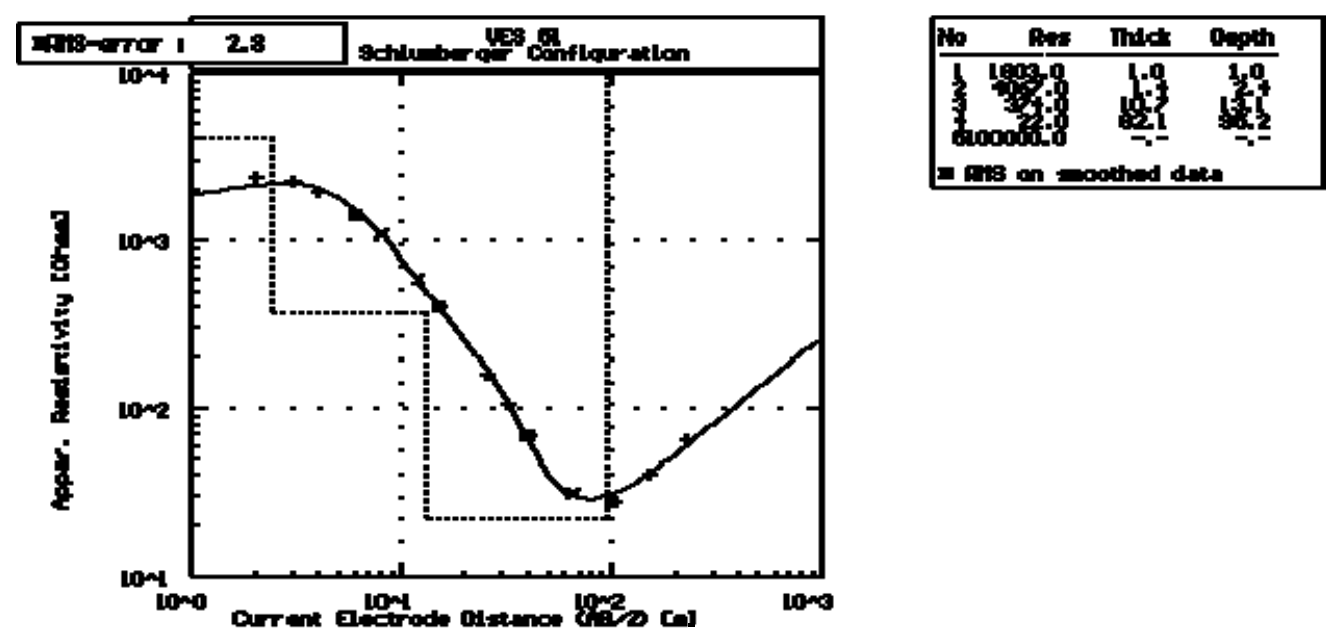

(HKH)
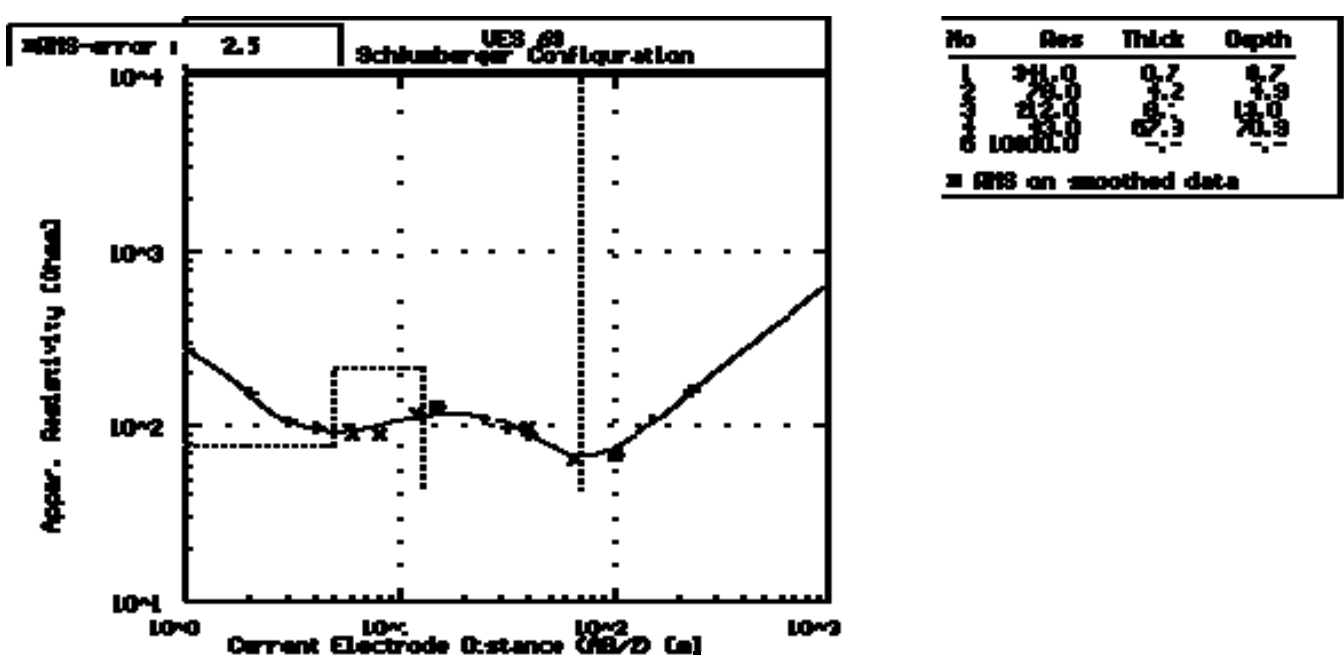

(KHKH)
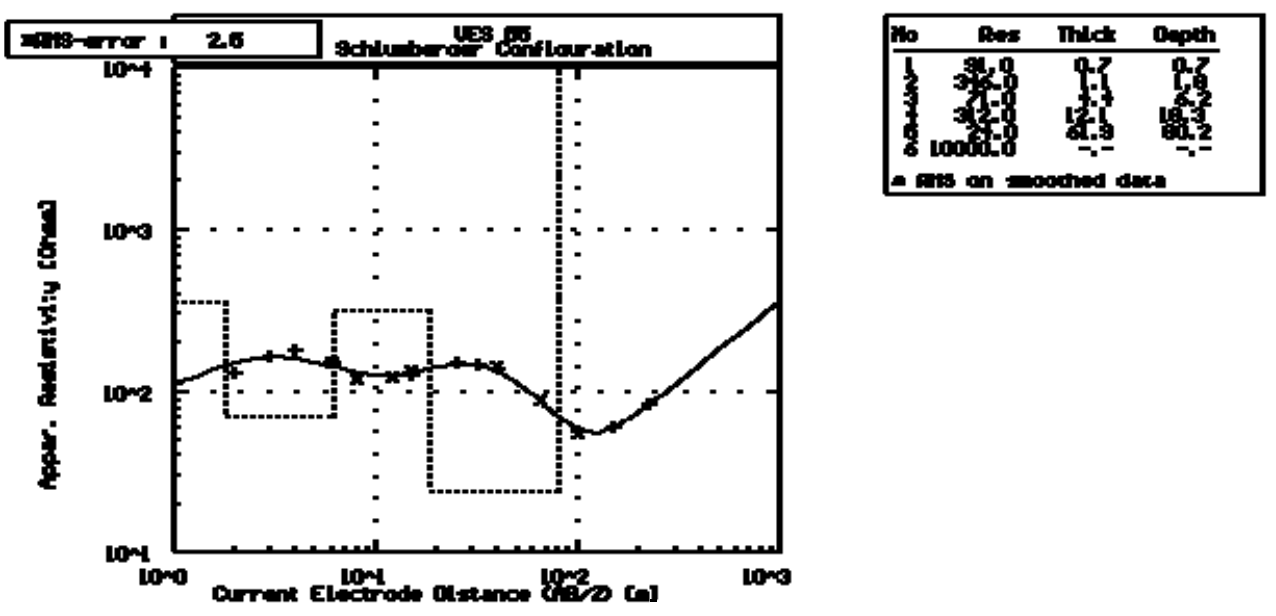

Figure 5 (b). Computer interpretation results and curve types 
Table 1. Classification of soil resistivity in terms of corrosivity (based on Baeckmann \& Schwenk, 1975; Agunloye, 1984; Oladapo et al., 2004)

\begin{tabular}{cc}
\hline Soil Resistivity (ohm-m) & Soil Corrosivity \\
\hline Up to 10 & Very Strongly Corrosive (VSC) \\
$10-60$ & Moderately Corrosive (MC) \\
$60-180$ & Slightly Corrosive (SC) \\
180 and above & Practically Non - Corrosive (PNC) \\
\hline
\end{tabular}

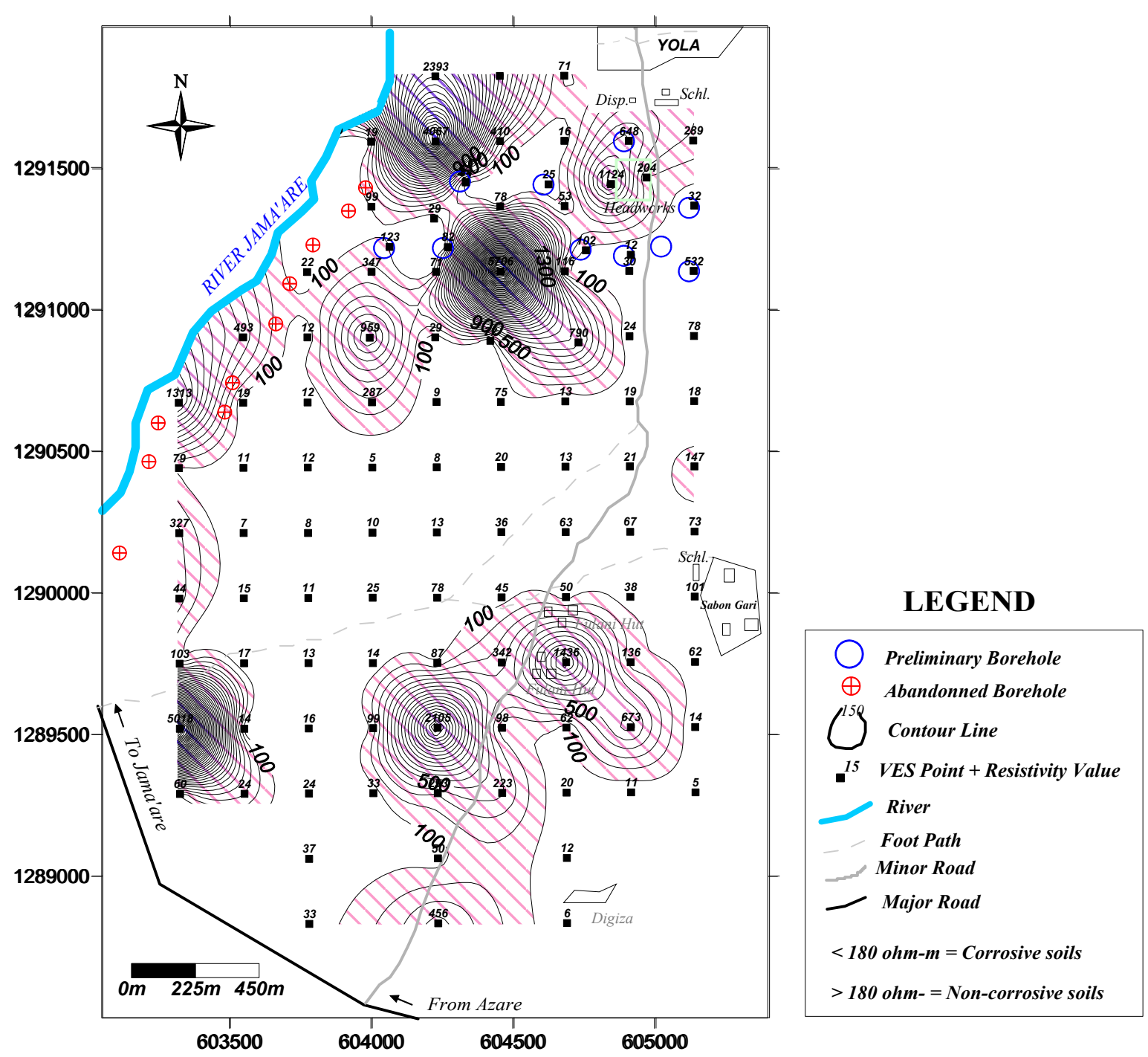

Figure 6. Corrosivity map of the study area 
Table 2. Modified longitudinal conductance/protective capacity rating (after Henriet, 1976; Oladapo et al., 2004)

\begin{tabular}{cc}
\hline Longitudinal Conductance (mhos) & Protective Capacity rating \\
\hline$>10$ & Excellent \\
$5-10$ & Very good \\
$0.8-4.9$ & Good \\
$0.2-0.79$ & Moderate \\
$0.1-0.19$ & Weak \\
$<0.1$ & Poor \\
\hline
\end{tabular}

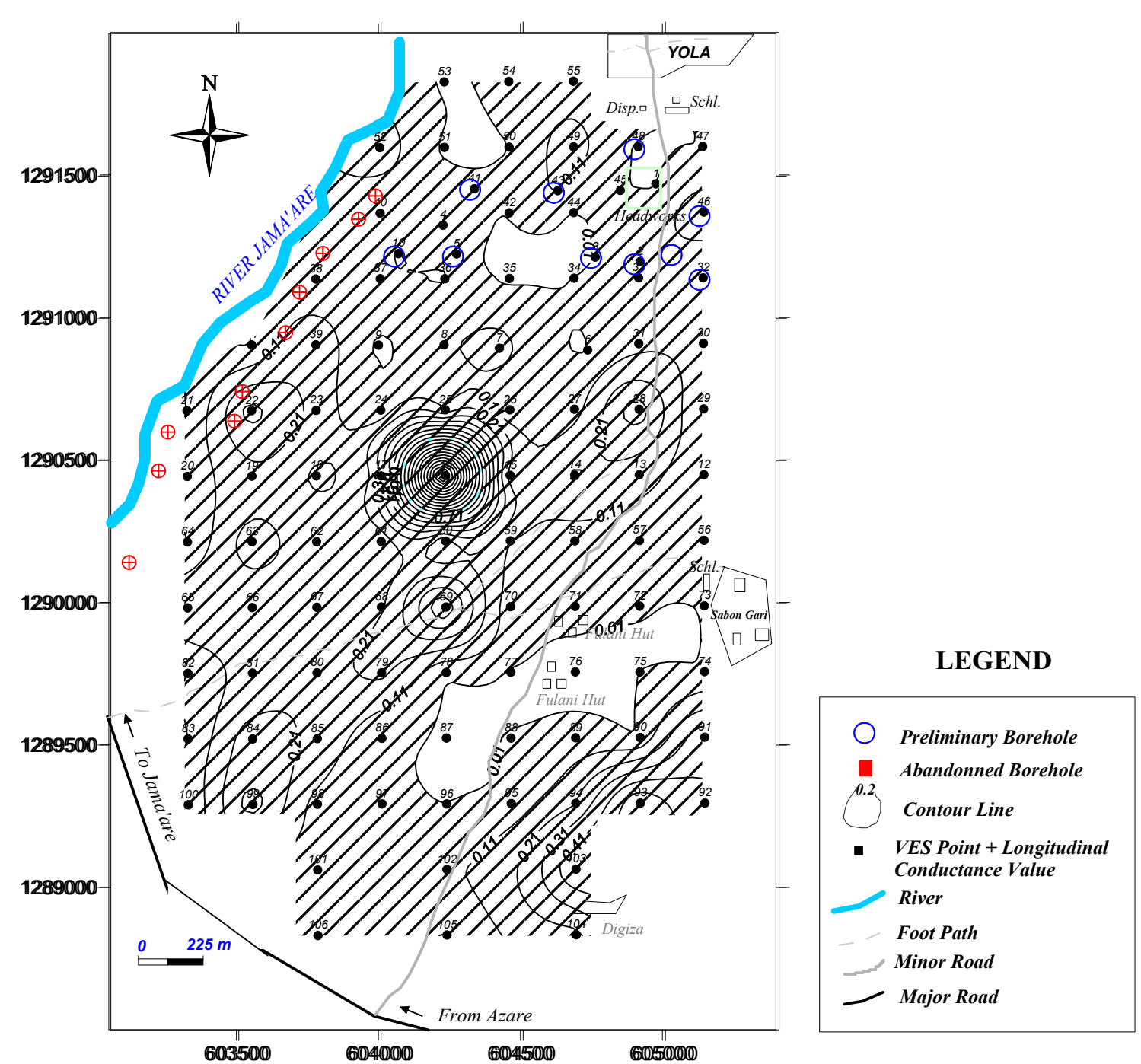

Figure 7. Topsoil longitudinal unit conductance map

\section{Conclusion}

\subsection{Conclusion}

The north central, southwestern, southern and northern parts of the study area contain corrosive topsoils with low resistivity $(\rho<180 \Omega-\mathrm{m}$ ), while the eastern, the southern and western parts of the area with high resistivity topsoils are precisely non corrosive. Hence, metallic utilities/pipes etc required for reticulation works buried within the superficial layer in the area are susceptible to corrosion suggesting a significant contribution of clayey matrix in the layer. 
The longitudinal conductance map reveals that above $95 \%$ of the study area are characterized by topsoil with poor to weak protective capacity. This implies that alluvium aquifers, the most prolific in the basin are not protected enough from surface pollutant(s) in most part of the area, while the remaining other few areas even at relatively shallow depth are significantly protected by variably thick clay/sandy clay topsoil which is annually reinforced by the flood activities of the meandering Jama'are river.

The study, therefore, has helped to evaluate the superficial topsoil materials overlying the alluvium aquifer in the study area and enables the assessment of the vulnerability of aquifer(s) to surface pollutants such as chemical fertilizers frequently used by farmers within the Fadama floodplain basin.

\subsection{Recommendation}

However, the challenges of long - term safe rate of the aquifers vis-à-vis ever changing climatic factors are important considerations in the assessment of the vulnerability of aquifer(s) to surface pollutants in any parts of the basin. While it is recommended that further study be carried out to assess the long - term safe rate of aquifers from a combination of hydrometerological, geophysical and geochemical techniques, the geochemical tool can be used in such a study.

\section{Acknowledgement}

The management of Aim Consultants, Lagos is appreciated for financing and providing logistic support for the data acquisition.

\section{References}

Agunloye, O. (1984). Soil corrosivity along pipe routes. Journal of Mining and Geology, 25.

Ako, B. D., \& Olorunfemi, M. O. (1989). Geoelectric survey for groundwater in the Newer Basalts of Vom, Plateau State. Journal of Mining and Geology, 25, 247-250.

Baeckmann, W. V., \& Schwenk, W. (1975). Handbook of cathodic protection. The theory and practice of electrochemical corrosion protection technique (p. 396). Surrey: Protucullin Press.

Bauchi State Agriculture Development Project. (1988). Bauchi State Hydrogeology-Hydrogeological unit descriptions by Wardrop Engineering Inc. Winnipeg, Canada, based on 1205 boreholes and 234 boreholes constructed under Contract BSADP-6 and BSADP-19 respectively.

Bierschenk, W. H. (1964). Determining well efficiency by multiple step-drawdown tests. Publication, 64th International Assoc. of Scient. Hydrology.

Carter, J. D., Barber, W., Tait, E. A., \& Jones, G. D. (1963). The Geology of part of Adamawa, Bauchi and Bornu Provinces in North Eastern Nigeria. Explanation on 1:250,000 sheets Nos. 25, 37 and 47. Geological Survey Bulletin, 30 .

F. S. N. (1978). National Atlas. Federal Survey of Nigeria (1st ed., pp. 5-11, 136).

Forum Umwelt, \& Entwickling. (2001). Policy paper for Bonn Intern. Conference on freshwater, World Water Conference, 4th Dec., 2001.

Geological Survey of Nigeria. (1978). Geological Map of Nigeria, on scale 1:2,000,000. Printed and published by Directorate of Federal Surveyors, Federal Ministry of Housing and Surveys, Nigeria.

Henriet, J. P. (1976). Direct application of the Dar Zarrouk parameters in groundwater surveys. Geophysical Prospecting, 24. http://dx.doi.org/10.1111/j.1365-2478.1976.tb00931.x

Maillet, R. (1947). The fundamental equations of electrical prospecting. Geophysics, 3, 529-556.

Matheis, G. (1989). Short review of the geology of the Chad Basin in Nigeria in Geology of Nigeria. In Kogbe, C. A. (Ed.), Rockview International, Jos. Nig., 341-346.

Mbonu, P. D. C., Ebeniro, J. O., Ofoegbu, C. O., \& Ekine, A. S. (1991). Geoelectric sounding for the determination of aquifer characteristic in parts of Umuahia area of Nigeria. Geophysics, 56, 284-291. http://dx.doi.org/10.1190/1.1443042

Mohammed. (2007). Hydrogeophysical Investigation of parts of the River Jama are Floodplain, West Chad Basin, Northeastern Nigeria (pp. 1-289). Unpubl. Ph.D Thesis Obafemi Awolowo University, Ile - Ife. Nigeria.

Niwas, S., \& Singhai, D. C. (1981). Estimation of aquifer transmissivity from Dar-Zarrouk Parameters in porous media. Journal of Hydrology, 50, 393-399. http://dx.doi.org/10.1016/0022-1694(81)90082-2 
Oastridge, J. W., \& Trent, S. (1999). Why is fresh water an issue for business? Background Paper Can 176-Qatr UN-CDS (p. 9).

Offodile, M. E. (1992). An approach to Groundwater Study and Development in Nigeria. Mecon Services Ltd. Jos. Nigeria.

Offodile, M. E. (2002). Groundwater study and development in Nigeria. Mecon Services Ltd. Jos. Nigeria (pp. 30-36, 76-103).

Oladapo, M. I., Mohammed, M. Z., Adeoye, O. O., \& Adetola, O. O. (2004). Geoelectric investigation of the Ondo-State Housing Corporation Estate, Ijapo, Akure, Southwestern Nigeria. Journal of Mining and Geology, 40(1), 41-48.

Olayinka, A. I., \& Olorunfemi, M. O. (1992). Determination of geoelectrical characteristics in Okene area and implications for Borehole siting. Journal of Mining and Geology, 28(2), 403-412.

Olorunfemi, M. O., \& Fasuyi, S. A. (1993). Aquifer types and the geoelectric/hydrogeologic characteristics of part of the central basement terrain of Nigeria (Niger State). Journal of African Earth Sciences, 16, 309-317. http://dx.doi.org/10.1016/0899-5362(93)90051-Q

Olorunfemi, M. O., Ojo, J. S., \& Akintunde, M. O. (1999). Hydrogeophysical evaluation of the groundwater potentials of the Akure metropolis. Journal of Mining and Geology, 35(2), 207-228.

Olorunfemi, M. O., \& Okhue, E. T. (1992). Hydrogeologic and geologic significance of a geoelectric survey at Ile-Ife, Nigeria. Journal of Mining and Geology, 28(2), 221-229.

Omosuyi, G. O., Ojo, J. S., \& Enikanselu, P. A. (2003). Geophysical investigation for groundwater around Obanla-Obakekere in Akure area within the Basement Complex of Southwestern Nigeria. Journal of Mining and Geology.

Zohdy, A. A. R. (1973). The use of Schlumberger and equational sounding of groundwater investigation near El Pasco, Texas. Geophysics, 54, 38-48.

Zohdy, A. A. R., Eaton, G. P., \& Mabey, D. R. (1974). Application of surface geophysics to groundwater investigations, techniques of water resources investigations of the U.S. Geological Survey. Washington, D. C. Book 2 (pp. 195-205). 


\section{Appendix}

Dar Zarrouk Parameters obtained from First Order Geoelectric Parameters.

\begin{tabular}{|c|c|c|c|c|c|c|}
\hline $\begin{array}{c}\text { VES } \\
\text { Station }\end{array}$ & $\begin{array}{l}\text { Topsoil } \\
s=\frac{h_{t s}}{\rho_{t s}}\end{array}$ & $\mathrm{~S}=\sum_{\mathrm{i}=1 \rho_{\mathrm{i}}}^{\mathrm{n}}$ & $\mathrm{T}=\sum_{\mathrm{i}=1}^{\mathrm{n}} \mathrm{h}_{\mathrm{i}} \rho_{\mathrm{i}}$ & $\rho_{L}=\frac{\sum_{i=1}^{n} h_{i}}{\sum_{i=1}^{n} \frac{h_{i}}{\rho_{i}}}$ & $\rho_{t}=\frac{\sum_{i=1}^{n} h_{i} \rho_{i}}{\sum_{i=1}^{n} h_{i}}$ & $\begin{array}{l}\text { Coefficient of } \\
\text { Anisotropy } \\
\lambda=\sqrt{ }\left(\rho_{\mathrm{t}} / \rho_{\mathrm{L}}\right)\end{array}$ \\
\hline 1 & 0.00294 & 0.47228 & 2810.6 & 56.3228 & 105.662 & 1.36967 \\
\hline 2 & 0.11667 & 2.61013 & 5437.2 & 38.1973 & 54.5356 & 1.19488 \\
\hline 3 & 0.00784 & 1.95654 & 5014.9 & 41.1952 & 62.2196 & 1.22897 \\
\hline 4 & 0.04483 & 2.91979 & 4368.9 & 29.5912 & 50.566 & 1.30722 \\
\hline 5 & 0.02195 & 1.22022 & 4239.6 & 41.7956 & 83.1294 & 1.4103 \\
\hline 6 & 0.00253 & 2.34481 & 6959.9 & 37.0179 & 80.1832 & 1.47176 \\
\hline 7 & 0.16818 & 2.79149 & 4463.5 & 27.8704 & 57.3715 & 1.43475 \\
\hline 8 & 0.10689 & 1.70883 & 5361.5 & 45.1186 & 69.5396 & 1.24148 \\
\hline 9 & 0.00146 & 1.20580 & 5912.3 & 51.7497 & 94.7484 & 1.35311 \\
\hline 10 & 0.00894 & 0.62933 & 1612.3 & 76.2714 & 194.583 & 1.59725 \\
\hline 11 & 0.00081 & 0.26385 & 1612.6 & 69.736 & 87.6413 & 1.12105 \\
\hline 12 & 0.01497 & 2.78253 & 13424.4 & 54.914 & 87.856 & 1.26486 \\
\hline 13 & 0.16191 & 1.93377 & 6368.1 & 48.2995 & 68.1809 & 1.18812 \\
\hline 14 & 0.22308 & 4.62863 & 7763.3 & 37.9162 & 44.2353 & 1.08012 \\
\hline 15 & 0.165 & 2.71483 & 4128 & 35.3244 & 43.0448 & 1.10388 \\
\hline 16 & 2.225 & 1.87408 & 4223.9 & 42.3675 & 53.1977 & 1.12055 \\
\hline 17 & 0.26 & 1.73279 & 2327 & 23.2573 & 57.7419 & 1.57567 \\
\hline 18 & 0.09167 & 2.34469 & 5913.8 & 46.232 & 54.5554 & 1.08629 \\
\hline 19 & 0.19091 & 2.62051 & 8323.1 & 52.0128 & 61.0646 & 1.08353 \\
\hline 20 & 0.01139 & 1.80258 & 11871.5 & 22.4125 & 293.849 & 3.6209 \\
\hline 21 & 0.00129 & 2.27867 & 7694.2 & 40.1111 & 84.1816 & 1.44869 \\
\hline 22 & 0.35263 & 2.12974 & 2885 & 33.3374 & 40.6338 & 1.10402 \\
\hline 23 & 0.19167 & 1.77088 & 4101.4 & 45.2318 & 51.2035 & 1.06397 \\
\hline 24 & 0.01603 & 0.90812 & 5786.9 & 62.1064 & 102.605 & 1.28533 \\
\hline 25 & 0.12222 & 2.59733 & 2307.6 & 21.9071 & 40.5554 & 1.3606 \\
\hline 26 & 0.03067 & 2.27481 & 5388.9 & 38.4208 & 61.6579 & 1.26681 \\
\hline 27 & 0.06154 & 1.65986 & 3921.8 & 31.8702 & 74.1361 & 1.52519 \\
\hline 28 & 0.37895 & 2.9901 & 5819.7 & 40.5338 & 48.0173 & 1.0884 \\
\hline 29 & 0.01278 & 2.58527 & 9399.8 & 52.1029 & 69.7832 & 1.1573 \\
\hline 30 & 0.07308 & 1.80700 & 13808.5 & 78.2512 & 97.6556 & 1.11713 \\
\hline 31 & 0.08333 & 5.04665 & 8506.9 & 34.4981 & 48.8621 & 1.19011 \\
\hline 32 & 0.00658 & 0.57368 & 4562.2 & 71.6427 & 111.002 & 1.24474 \\
\hline 33 & 0.07333 & 1.80282 & 2187.3 & 28.8437 & 42.0635 & 1.20761 \\
\hline 34 & 0.01034 & 2.24827 & 6024.4 & 31.2241 & 85.8177 & 1.65784 \\
\hline 35 & 0.00438 & 1.82338 & 22421.7 & 60.163 & 204.391 & 1.84317 \\
\hline
\end{tabular}




\section{Appendix continued}

Dar Zarrouk Parameters obtained from First Order Geoelectric Parameters

\begin{tabular}{|c|c|c|c|c|c|c|}
\hline $\begin{array}{c}\text { VES } \\
\text { Station }\end{array}$ & $\begin{array}{l}\text { Topsoil } \\
s=\frac{h_{t s}}{\rho_{t s}}\end{array}$ & $\mathrm{~S}=\sum_{\mathrm{i}=1 \rho_{\mathrm{i}}}^{\mathrm{n}} \frac{\mathrm{h}_{\mathrm{i}}}{\mathrm{p}_{\mathrm{i}}}$ & $\mathrm{T}=\sum_{\mathrm{i}=1}^{\mathrm{n}} \mathrm{h}_{\mathrm{i}} \rho_{\mathrm{i}}$ & $\rho_{L}=\frac{\sum_{i=1}^{n} h_{i}}{\sum_{i=1}^{n} \frac{h_{i}}{\rho_{i}}}$ & $\rho_{t}=\frac{\sum_{i=1}^{n} h_{i} \rho_{i}}{\sum_{i=1}^{n} h_{i}}$ & $\begin{array}{c}\text { Coefficient of } \\
\text { Anisotropy } \\
\lambda=\sqrt{ }\left(\rho_{\mathrm{t}} / \rho_{\mathrm{L}}\right)\end{array}$ \\
\hline 36 & 0.05634 & 2.59374 & 10251 & 32.1543 & 122.914 & 1.95515 \\
\hline 37 & 0.01844 & 3.61291 & 10308.6 & 20.5098 & 139.117 & 2.60442 \\
\hline 38 & 0.06364 & 1.36262 & 676.8 & 21.2091 & 23.4187 & 1.0508 \\
\hline 39 & 0.2 & 1.25489 & 936.3 & 18.0893 & 41.2467 & 1.51002 \\
\hline 40 & 0.01919 & 1.20485 & 9887.7 & 78.3499 & 104.743 & 1.15622 \\
\hline 41 & 0.025 & 2.17961 & 3076.2 & 24.3163 & 58.0415 & 1.54497 \\
\hline 42 & 0.00897 & 3.54129 & 5611.8 & 34.6766 & 45.6987 & 1.14798 \\
\hline 43 & 0.12 & 2.79793 & 3386.6 & 17.9061 & 67.5968 & 1.94295 \\
\hline 44 & 0.00317 & 1.95447 & 4410.8 & 44.5645 & 50.6406 & 1.06599 \\
\hline 45 & 0.01423 & 0.48250 & 4589.2 & 68.3936 & 139.067 & 1.42595 \\
\hline 46 & 0.18125 & 2.50062 & 2981.3 & 25.1937 & 47.3222 & 1.37052 \\
\hline 47 & 0.01142 & 1.67842 & 5955.2 & 42.3018 & 83.8761 & 1.40812 \\
\hline 48 & 0.00339 & 1.00701 & 5746 & 55.7097 & 102.424 & 1.35593 \\
\hline 49 & 0.15625 & 1.71645 & 3300.2 & 32.6254 & 58.9321 & 1.344 \\
\hline 50 & 0.00366 & 1.41644 & 6246.8 & 60.0097 & 73.4918 & 1.10665 \\
\hline 51 & 0.00059 & 3.75674 & 15604 & 25.3411 & 163.908 & 2.54324 \\
\hline 52 & 0.18421 & 5.14708 & 4278.5 & 25.8594 & 32.145 & 1.11493 \\
\hline 53 & 0.00213 & 2.27537 & 18729.3 & 26.3693 & 312.155 & 3.44061 \\
\hline 54 & - & - & Bad data & - & - & - \\
\hline 55 & 0.08732 & 2.70111 & 5698.6 & 29.6915 & 71.0549 & 1.54697 \\
\hline 56 & 0.04521 & 2.25561 & 11355.6 & 59.3188 & 84.87 & 1.19614 \\
\hline 57 & 0.03582 & 0.30692 & 8582.8 & 154.436 & 181.072 & 1.08281 \\
\hline 58 & 0.07619 & 2.49774 & 9304.6 & 55.0098 & 67.7191 & 1.10952 \\
\hline 59 & 0.11389 & 1.32503 & 5262.9 & 38.9426 & 101.994 & 1.61836 \\
\hline 60 & 0.1 & 1.02458 & 4397.3 & 60.2197 & 71.269 & 1.08788 \\
\hline 61 & 0.12 & 0.75790 & 3737.3 & 51.5898 & 95.5831 & 1.36116 \\
\hline 62 & 0.175 & 0.95751 & 3613.6 & 46.4745 & 81.2045 & 1.32185 \\
\hline 63 & 0.25714 & 1.13708 & 3850.3 & 49.2488 & 68.7554 & 1.18156 \\
\hline 64 & 0.00275 & 1.51219 & 15058.2 & 54.0273 & 184.311 & 1.84701 \\
\hline 65 & 0.21136 & 1.42295 & 5040.6 & 42.1659 & 84.01 & 1.41151 \\
\hline 66 & 0.16 & 1.71177 & 2251.9 & 22.4913 & 58.4909 & 1.61264 \\
\hline 67 & 0.13636 & 1.53675 & 6280.7 & 55.2464 & 73.9776 & 1.15717 \\
\hline 68 & 0.184 & 1.82410 & 4407.8 & 45.6663 & 52.9148 & 1.07644 \\
\hline 69 & 0.6282 & 1.44707 & 4567.9 & 48.9956 & 64.4274 & 1.14672 \\
\hline 70 & 0.06 & 2.17757 & 4496.1 & 35.6361 & 57.9394 & 1.27509 \\
\hline
\end{tabular}




\section{Appendix continued}

Dar Zarrouk Parameters obtained from First Order Geoelectric Parameters

\begin{tabular}{|c|c|c|c|c|c|c|}
\hline $\begin{array}{c}\text { VES } \\
\text { Station }\end{array}$ & $\begin{array}{l}\text { Topsoil } \\
s=\frac{h_{t s}}{\rho_{t s}}\end{array}$ & $\mathrm{~S}=\sum_{\mathrm{i}=1 \rho_{\mathrm{i}}}^{\mathrm{n}} \frac{\mathrm{h}_{\mathrm{i}}}{\rho_{\mathrm{i}}}$ & $\mathrm{T}=\sum_{\mathrm{i}=1}^{\mathrm{n}} \mathrm{h}_{\mathrm{i}} \mathrm{\rho}_{\mathrm{i}}$ & $\rho_{\mathrm{L}}=\frac{\sum_{\mathrm{i}=1}^{\mathrm{n}} \mathrm{h}_{\mathrm{i}}}{\sum_{\mathrm{i}=1}^{\mathrm{n}} \frac{\mathrm{h}_{\mathrm{i}}}{\rho_{\mathrm{i}}}}$ & $\rho_{t}=\frac{\sum_{i=1}^{n} h_{i} \rho_{i}}{\sum_{i=1}^{n} h_{i}}$ & $\begin{array}{l}\text { Coefficient of } \\
\text { Anisotropy } \\
\lambda=\sqrt{ }\left(\rho_{\mathrm{t}} / \rho_{\mathrm{L}}\right)\end{array}$ \\
\hline 71 & 0.03 & 0.84686 & 13267.7 & 105.803 & 148.077 & 1.18303 \\
\hline 72 & 0.01842 & 2.60283 & 6303.4 & 35.0004 & 69.1921 & 1.40602 \\
\hline 73 & 0.01188 & 0.65846 & 3922.8 & 73.6573 & 80.8825 & 1.0479 \\
\hline 74 & 0.16129 & 2.59516 & 5113.1 & 19.151 & 102.879 & 2.31776 \\
\hline 75 & 0.01029 & 0.75159 & 6199.4 & 44.5722 & 185.057 & 2.03761 \\
\hline 76 & 0.00216 & 2.62614 & 7219.9 & 17.1354 & 160.442 & 3.05994 \\
\hline 77 & 0.00499 & 1.67093 & 7506 & 27.8287 & 161.419 & 2.40841 \\
\hline 78 & 0.01494 & 1.91777 & 6374 & 24.5597 & 135.329 & 2.34738 \\
\hline 79 & 0.23571 & 4.56231 & 6321.9 & 34.259 & 40.4472 & 1.08657 \\
\hline 80 & 0.19231 & 4.05397 & 2987.9 & 23.1378 & 31.8539 & 1.17333 \\
\hline 81 & 0.14118 & 2.24836 & 4423.9 & 32.3792 & 60.7679 & 1.36995 \\
\hline 82 & 0.00971 & 1.61246 & 9961 & 63.1954 & 97.7527 & 1.24372 \\
\hline 83 & 0.00062 & 1.68924 & 19606.3 & 49.0161 & 236.791 & 2.19793 \\
\hline 84 & 0.26429 & 2.31413 & 1964.8 & 19.2729 & 44.0538 & 1.51188 \\
\hline 85 & 0.18125 & 1.58725 & 3784.2 & 42.2115 & 56.4806 & 1.15674 \\
\hline 86 & 0.03838 & 1.71446 & 6190.6 & 34.7048 & 104.044 & 1.73146 \\
\hline 87 & 0.00143 & 1.53058 & 18515.8 & 67.2946 & 179.765 & 1.63442 \\
\hline 88 & 0.01633 & 1.37328 & 6821.2 & 37.8654 & 131.177 & 1.86126 \\
\hline 89 & 0.04839 & 2.26972 & 3555.2 & 30.8848 & 50.7161 & 1.28145 \\
\hline 90 & 0.00847 & 2.31775 & 10420.3 & 45.9497 & 97.8432 & 1.45923 \\
\hline 91 & 0.38571 & 2.73644 & 12584.2 & 63.4766 & 72.4479 & 1.06833 \\
\hline 92 & 0.42 & 4.80761 & 3295 & 19.9059 & 34.4305 & 1.31517 \\
\hline 93 & 0.60901 & 3.89332 & 3147.4 & 24.7861 & 32.6155 & 1.14712 \\
\hline 94 & 0.195 & 1.87181 & 1218.1 & 23.7203 & 27.4347 & 1.07545 \\
\hline 95 & 0.03408 & 1.91341 & 14297.4 & 80.9025 & 92.3605 & 1.06847 \\
\hline 96 & 0.00921 & 2.26561 & 5169.2 & 25.9092 & 88.0613 & 1.8436 \\
\hline 97 & 0.04242 & 1.18012 & 4880.2 & 53.6385 & 77.0964 & 1.19889 \\
\hline 98 & 0.075 & 2.15479 & 6859.8 & 50.121 & 63.5167 & 1.12573 \\
\hline 99 & 0.35833 & 3.00111 & 3993.2 & 21.9919 & 60.503 & 1.65866 \\
\hline 100 & 0.01 & 3.67137 & 6427 & 20.7824 & 84.2333 & 2.01323 \\
\hline 101 & 0.02162 & 0.91509 & 9533.8 & 95.0725 & 109.584 & 1.07361 \\
\hline 102 & 0.106 & 0.67539 & 4411.5 & 57.4486 & 113.698 & 1.40682 \\
\hline 103 & 0.5 & 1.74308 & 2548 & 32.127 & 45.5 & 1.19007 \\
\hline 104 & 0.17619 & 2.38709 & 19015.2 & 35.9853 & 221.364 & 2.48023 \\
\hline 105 & 0.00789 & 1.00137 & 10146.4 & 80.8896 & 125.264 & 1.24442 \\
\hline 106 & 0.06969 & 1.24910 & 3995 & 46.8337 & 68.2906 & 1.20754 \\
\hline
\end{tabular}

